\title{
ON THE TEMPERATURE REGIME OF CONTINENTAL- TYPE GLACIERS IN CHINA
}

\author{
By Huang MaOhuan, ${ }^{*}$ Wang Zhongxiang, $\dagger$ and Ren JiAwen $\ddagger$ \\ (Lanzhou Institute of Glaciology and Cryopedology, Academia Sinica, Lan-chou (Lanzhou), \\ Kansu (Gansu), 730000, China)
}

\begin{abstract}
Ice temperature data collected from the area of continental-type glaciers in China since 1959 are analysed. Formulae for the temperature stratification of the active layer and for annual mean temperature profiles are suggested. The temperature in continental-type glaciers in China is quite low, rising rapidly with depth. A major part of the bottom of most glaciers reaches the pressure-melting point, with basal sliding. The extreme huge valley glacier will change from a cold glacier into a temperate one when it descends to the district where the climate is temperate. The ice temperature of the lower bound of the active layer at the altitude of the equilibrium line is 1.8-3.7 deg higher than the annual mean air temperature at the same level. The western section of Ch'i-lien Shan (Qilian Shan) may be the place where the temperature of alpine glaciers is the lowest of the middle and low latitudes. The infiltration zone is warmed significantly by the infiltration and recongelation process. A scheme showing how the lower bound temperature of the active layer changes with glacial zones is drawn.
\end{abstract}

RÉSUMÉ. Le régime des températures dans les glaciers de type continental en Chine. On analyse les températures de la glace recueillies sur glaciers de type continental en Chine depuis 1959. On a suggéré des formules pour rendre compte de la stratification des températures du niveau actif, et pour le profil de température moyenne annuelle. La température dans les glaciers de type continental en Chine est très basse, s'élevant rapidement en profondeur. La plus grande partie du fond, dans la plupart des glaciers atteint le point de fusion correspondant à la pression, avec glissement sur le fond. Un très grand glacier de vallée se transforme de glacier froid en glacier tempéré lorsqu'il aborde une région oủ le climat est tempéré. La température de la glace à la limite inférieure du niveau actif, à l'altitude de la ligne d'équilibre est de 1,8 à 3,7 deg supérieure à la température moyenne annuelle de l'air à la même altitude. La section occidentale du Ch'i-lien Shan (Qilian Shan) est peut-être l'endroit où la température d'un glacier alpin est la plus basse dans les latitudes moyennes et basses. La zone d'infiltration est, de manière significative, réchauffée par un processus d'infiltration et de regel. On a dressé un schéma montrant les variations de la température de la limite inférieure du niveau actif avec les zones de glaciations.

ZuSAMMENFASSUNG. Über den Wärmehaushalt der kontinentalen Gletscher in China. Die Beobachtungen der Eistemperaturen aus dem Gebiet der kontinentalen Gletscher in China seit 1959 werden analysiert. Formeln für die Temperaturschichtung im aktiven Eis und für ein Profil der Jahresmitteltemperatur werden vorgelegt. Die Temperatur in den kontinentalen Gletschern Chinas ist sehr niedrig, steigt jedoch schnell mit der Tiefe. Ein Grossteil der Grundschicht in den meisten Gletschern befindet sich auf dem Druckschmelzpunkt und gleitet am Untergrund. Extrem mächtige Talgletscher wandeln sich von kalten zu temperierten Gletschern, wenn sie in den Bereich temperierten Klimas herabfliessen. An der unteren Grenze des aktiven Schichts in Höhe der Gleichgewichtslinie ist die Temperatur 1.8-3.7 deg höher als die Jahresmitteltemperatur in derselben Höhe. Der Westteil des Ch'i-lien Shan (Qilian Shan) dürfte der Ort sein, wo alpine Gletscher der mittleren und niedrigen Breiten ihre tiefste Temperatur erreichen. Die Sickerzone wird durch das Sickerwasser und die Wiedergefrierwärme beträchtlich erwärmt. Eine schematisch Darstellung zeigt die Veränderung der Temperatur der Untergrenze des aktiven Schichts innerhalb der vergletscherten Zonen.

\section{INTRODUCTION}

In China research on existing glaciers began in 1958. Early in the 1960's the glaciers in West China were classified into continental type and maritime type according to their main properties and geographical environments. To the former belong those in most parts of Ch'ing-hai-Hsitsang kao-yuan (Qinghai-Xizang gao-yuan-Tibetan Plateau) from the middle Himalaya Shan to Ch'i-lien Shan (Qilian Shan) and T'ien Shan (Tian Shan) with low precipitation and low temperature, while to the latter those in south-eastern parts of the Plateau with high monsoon precipitation (Shi and Xie, 1964; Shi and others, 1980). Among them the continental-type glaciers have been researched rather more, and their temperature measurement is taken as a

\footnotetext{
* Wade-Giles: Huang Mao-huan.

+ Wade-Giles: Wang Chung-hsiang.

¥ Wade-Giles: Jen Chia-wen.
} 


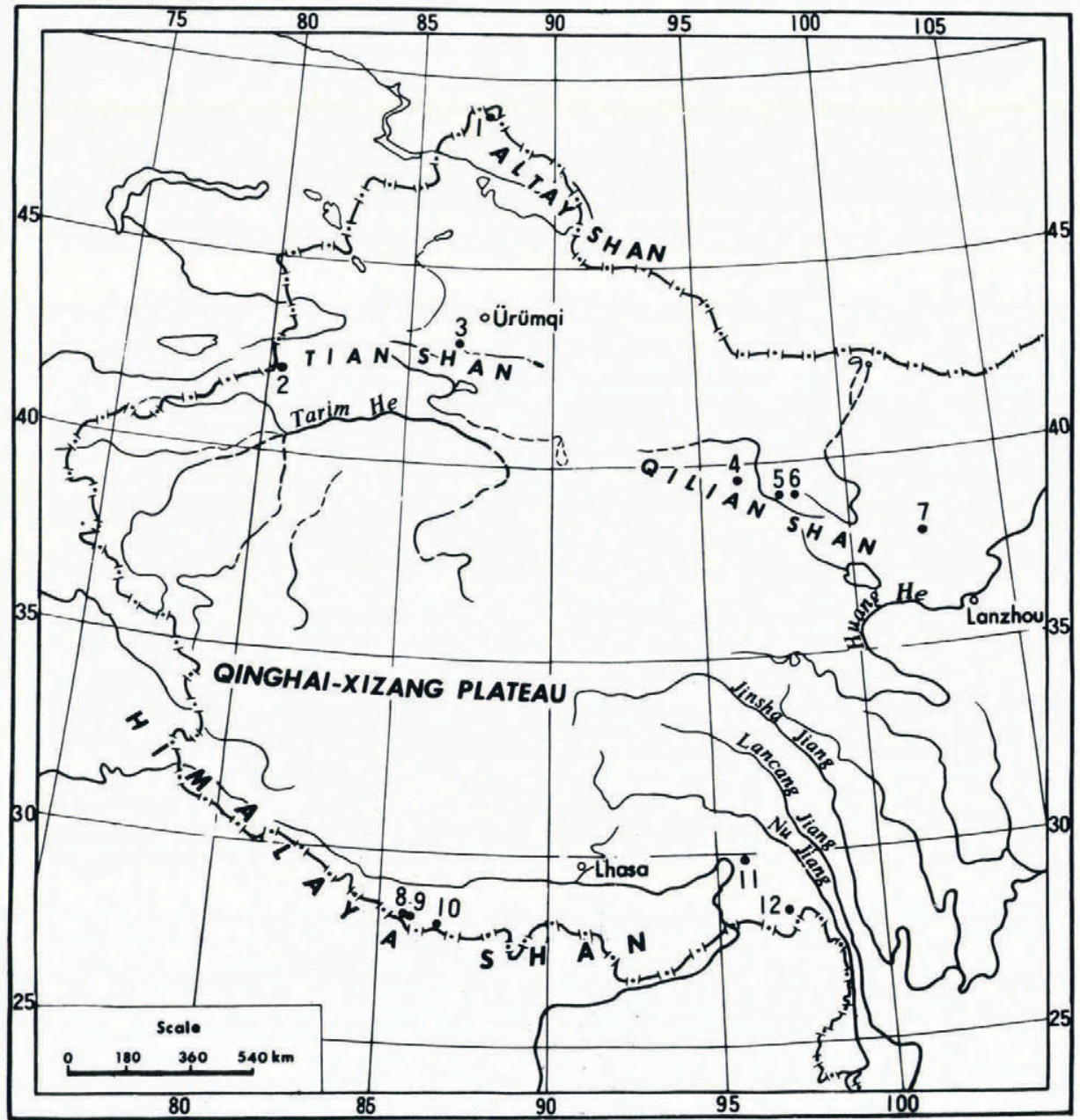

Fig. 1. Index map showing location of the glaciers where temperature has been measured in China. The Wade-Giles (or the conventional) transliteration of place-names on the map are:

$\begin{array}{ll}\text { Ürüqi: } & \text { Urumchi } \\ \text { Tian Shan: } & \text { T'ien Shan } \\ \text { Qilian Shan: } & \text { Ch'i-lien Shan } \\ \text { Huang He: } & \text { Hwang Ho } \\ \text { Lanzhou: } & \text { Lan-chou }\end{array}$

Qinghai-Xizang

Plateau:

Jinsha Jiang:

Lancang Jiang:

Nu Jiang:

\section{Ch'ing-hai-Hsi-tsang kao-yuan \\ Chi-sha chiang \\ Lan-ts'ang chiang \\ $\mathrm{Nu}$ chiang}

Locations indicated by numbers:

1. Ha-la-ssu ping-ch'uan (Ha-la-si bing-chuan), Altay, Shan.

2. Hsi-ch'iung-t'ai-lan ping-ch'uan (Xi-qiong-tai-lan bing-chuan), T'o-mu-erh feng (Tuo-mu-er feng).

3. No. 1 glacier, Urumchi river, T'ien Shan (Tian Shan).

4. Lao-hu-kou ping-ch'uan (Lao-hu-gou bing-chuan), Ch'i-lien Shan (Qilian Shan).

5. "Ch'i yi" ping-ch'uan ("Qi Yi" bing-chuan) Ch'i-lien Shan (Qilian Shan).

6. No. 5 glacier, Yang-lung he (Yang-long he), Ch'i-lien Shan (Qilian Shan).

7. No. 4 glacier, Shui-kuan he (Shui-guan he), Ch'i-lien Shan (Qilian Shan).

8. Ye-po-k'ang-chia-le ping-ch'uan (Ye-bo-kang-jia-le bing-chuan), Hsi-hsia-pang-ma feng (Xi-xia-bang-ma feng).

9. Na-k'e-to-la ping-ch'uan (Na-ke-duo-la bing-chuan), Hsi-hsia-pang-ma feng (Xi-xia-bang-ma feng).

10. Jung-pu ping-ch'uan (Rong-bu bing-chuan-"Rongbuk" glacier), Chu-mu-lang-ma feng (Zhu-mu-lang-ma feng).

11. Ku-hsiang ping-ch'uan (Gu-xiang bing-chuan), south-eastern Hsi-tsang (Xizang).

12. A-cha ping-ch'uan (A-zha bing-chuan), south-eastern Hsi-tsang (Xizang). 
significant project in their investigation. Since the first measurement (Dolgushin, 1961) taken in Ch'i-lien Shan (Qilian Shan) in 1959, temperature has so far been measured at 24 sites in 12 glaciers (Fig. 1). In many glaciers the temperature of the snow cover has also been measured. Furthermore, Chinese glaciologists have taken temperature measurements on Batura Glacier (lat. $36^{\circ} 35^{\prime}$ N., long. $74^{\circ} 23^{\prime}$ E.) (Batura Glacier Investigation Group, 1979) and Balt Bare Glacier (lat. $36^{\circ} 20^{\prime}$ N., long. $74^{\circ} 52^{\prime}$ E.) (Wang and others, in press) in Karakoram Mountains for a short time.

The ice temperature is usually measured using a copper resistance thermometer measured by a Wheatstone's bridge. For laying the thermometer, a hand drill and a steam drill are used to make holes, the maximum depth of which reaches $18 \mathrm{~m}$. Most drill holes are located in the ablation zone, while a few are in the accumulation zone.

The glaciers Ku-hsiang ping-ch'uan (Gu-xiang bing-chuan) and A-cha ping-ch'uan (A-zha bing-chuan) are located in south-eastern Hsi-tsang (Xizang-Tibet) as Figure 1 shows. They have temperatures equal to $0^{\circ} \mathrm{C}$ or so and belong to the maritime type, with which we will not be dealing in this paper for the time being. The rest of the glaciers shown in Figure 1 are of continental type. Shi and Xie (1964), Division of Glaciology, Lanzhou Institute of Glaciology, Cryopedology, and Desert Research (1975), and Shi and others (1980) have reviewed their temperature. Adding some of the latest data, we are going to undertake a comprehensive discussion of the temperature regime of the continental-type glaciers here.

\section{ICE TEMPERATURE REGIME IN THE ACTIVE LAYER}

Figure 2 shows the temperature stratification measured in No. 1 glacier, Urumchi river, weekly from June to September 1962, the first continuous measurements for a relatively long time in China. Figure 3 shows the stratification at the same place measured monthly from 1964 to 1966 , which is characterized by having the longest continual measuring time to a greater depth in China.

Figure 4 shows the stratification measured in No. 5 glacier, Yang-lung he (Yang-long he), weekly in 1977 with the greatest depth and different levels for comparison.

On the basis of analysing the data of No. 5 glacier, Yang-lung he (Yang-long he), for describing the ice-layer temperature regime with a period of one year, i.e. $\omega / 2 \pi=1 \mathrm{a}^{-1}$, Ren and

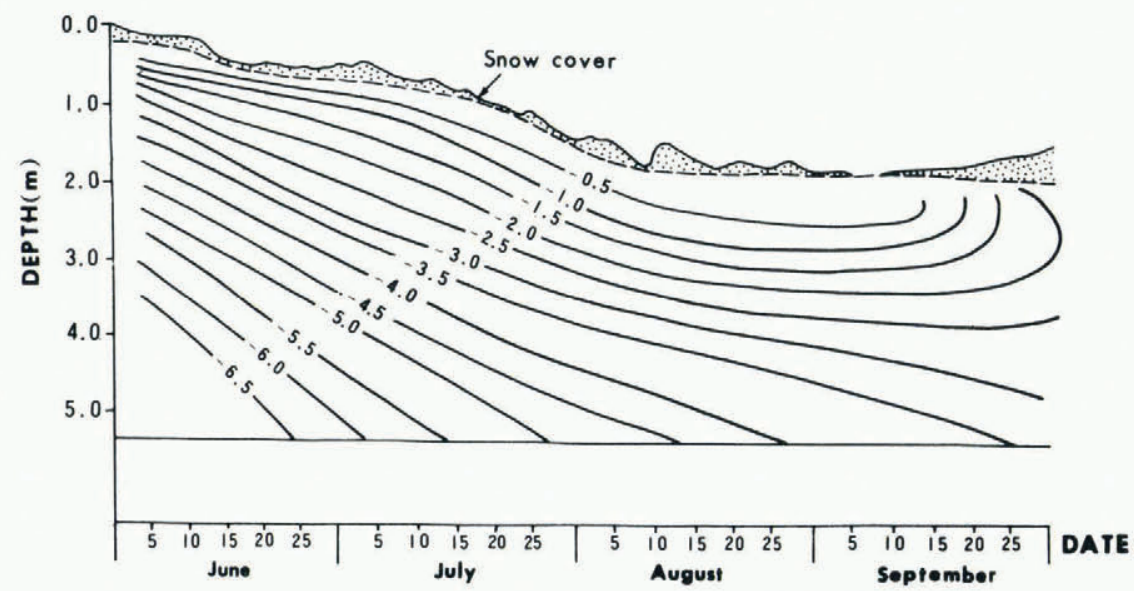

Fig. 2 The summer temperature stratification of the upper layer in No. 1 glacier, Urumchi river measured in 1962 at an altitude of $3825 \mathrm{~m}$ (ablation zone) (from Huang and Yuan, 1965). 


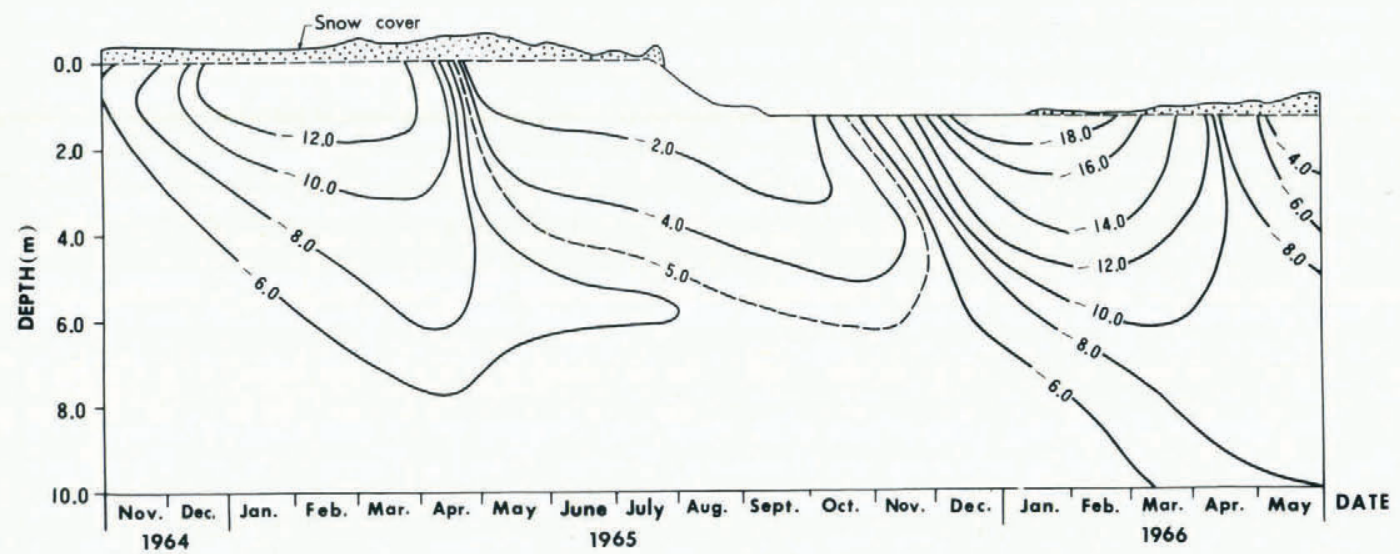

Fig. 3. The temperature stratification of active layer in No. 1 glacier, Urumchi river, measured from October 1964 to May 1966 at the altitude of $3845 \mathrm{~m}$ (ablation zone).

Huang (1981) have derived a semi-empirical formula as follows,

$$
\left.T(y, t)=T_{\mathrm{s}} \exp \left|-\beta y\left(\frac{\omega}{2 k}\right)^{1 / 2}\right| \sin \mid \omega t-y\left(\frac{\omega}{2 k}\right)^{1 / 2}\right]+T_{0}(y) \quad \text { for } y>3 m
$$

where $y$ is the coordinate of depth, with an origin on the glacial surface and a positive direction downwards; $t$ the coordinate of time; $T(y, t)$ is the temperature at a depth $y$ and time $t ; T_{\mathrm{s}}$ an apparent wave amplitude at the surface; $\omega / 2 \pi$ the frequency of temperature change; $k$ the thermal diffusivity; $\beta$ a factor for correcting the amplitude, being roughly $1.0 ; T_{0}(y)$ the equilibrium temperature at depth $y$, namely the annual mean temperature. 30 April was chosen to be $t=0$ so that the phase of the summer temperature wave gave a good fit to the sinusoid in Equation (1). By means of correlation analysis we obtain

$$
T_{0}(y)=\alpha+\gamma y \quad \text { for } y>3 \mathrm{~m}
$$

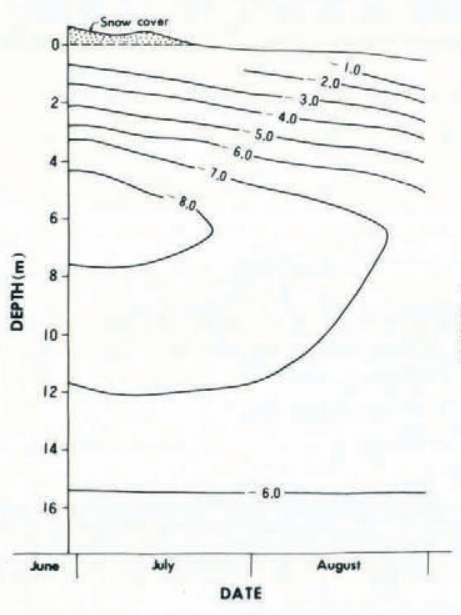

(a)

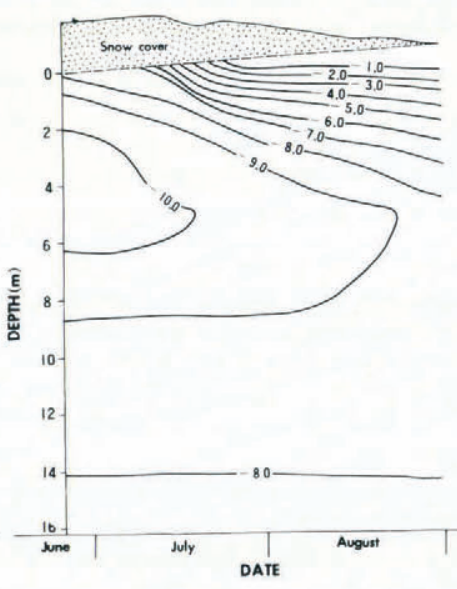

(b)

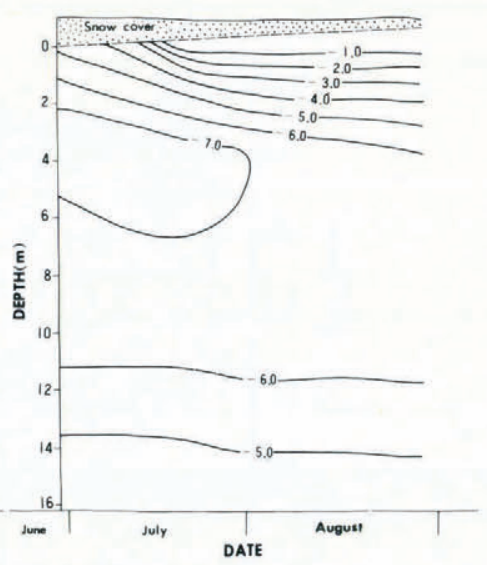

(c)

Fig. 4. The summer temperature stratification of the active layer in No. 5 glacier, Yang-lung he (Yang-long he), measured from June to August 1977. (a) at an altitude of $4513 \mathrm{~m}$ in ablation zone, (b) at an altitude of $4648 \mathrm{~m}$ near equilibrium line, (c) at an altitude of $4835 \mathrm{~m}$ infiltration zone. 
where $a$ is a constant and $\gamma$ the vertical temperature gradient.

The above two formulae can be applied to the level near the equilibrium line. In addition the analysis cannot ensure that conduction is the dominant factor for heat exchange when $y<3 \mathrm{~m}$, within which layer the heat exchange is complicated, and so there is some discrepancy between the Equation (1) (also Equation (2)) based on the heat-conduction equation and on the measured data.

Based on the picture described by Equation (1), we can divide the depth range within which we have temperature measurements into three layers: a surface layer, where an obvious temperature change occurs during all seasons of the year with a large amplitude and a variable sign of temperature gradient, so that the heat conducts sometimes upwards and sometimes downwards in this layer; a middle layer, where the temperature change becomes less and less during the year and the temperature gradient does not change sign, so the heat conduction always occurs in one direction in this layer; a deep layer, at the upper bound of which the yearly temperature change is less than $0.2 \mathrm{deg}$, so this layer can be considered to be lacking in yearly temperature change and the heat always conducts upwards. Sometimes the surface layer plus the middle layer is called the "active layer" (Avsyuk, 1956). The boundary between the surface layer and the middle layer is about $6 \mathrm{~m}$ deep. The lower bound of the active layer is at a depth of $15-20 \mathrm{~m}$. Taking account of the fact that the maximum depth to which we have measured the temperature is merely 16 or $18 \mathrm{~m}$, we take $16 \mathrm{~m}$ as the lower bound of the active layer for the moment. The temperature of the lower bound of the active layer, $T_{0}(16)$, can be considered an important characteristic of the glacial temperature regime, as we are going to mention later on.

\section{INFERENCE OF TEMPERATURE IN THE DEEP LAYER}

Measured data in the deep layer are lacking. But we may make an inference from the active layer. One can assume roughly that all the heat generated by friction concentrates at the glacier bottom, so that the geothermal flux combining with the generated heat is considered to be the heat input at the bottom (Budd, 1969). For a cold glacier in thermal steady state, the entire heat input $Q$ at the bottom per unit time, should transmit upwards in time, requiring a temperature gradient $G$, then,

$$
G=\frac{Q}{\lambda}
$$

where $\lambda$ is the conductivity.

There are only three kinds of temperature boundary condition at the glacial bottom; (a) the temperature of the interface between ice and bedrock is below $0^{\circ} \mathrm{C}$, ice and bedrock freeze together, namely $T_{\mathrm{b}}<\theta$ and $(\partial T / \partial y)_{\mathrm{b}}=G$ (where $T_{\mathrm{b}}$ and $(\partial T / \partial y)_{\mathrm{b}}$ are the ice temperature and temperature gradient at the interface respectively, and $\theta$ pressure-melting point); (b) the interface is at the pressure-melting point, but the bottom ice layer is below pressure-melting point, namely $T_{\mathrm{b}}=\theta$ and $0<(\partial T / \partial y)_{\mathrm{b}}<G$, a part of the heat input transmits upwards and another part is expended by melting the bottom ice; (c) there is a temperate layer at the bottom; i.e. $T_{\mathrm{b}}=\theta$ and $(\partial T / \partial y)_{\mathrm{b}}=0$, all the input is expended by melting without transmitting upwards. follows,

We can approximately estimate the depth $L$ at which the pressure-melting point occurs, as

$$
L=\frac{-T_{0}(16)}{\gamma}+16,
$$

for the above three boundary conditions, assuming the $\gamma$ within $L$ to be the same as that within the active layer. There are the following relations between $L$ and glacier thickness $H$, and 
between $G$ and $\gamma$, corresponding to the above three boundary conditions:

$$
\begin{aligned}
& L>H \text { and } G=\gamma \text { for condition (a); } \\
& L=H \text { for condition (b); } \\
& L<H \text { and } G>\gamma \text { for condition (c). }
\end{aligned}
$$

Equations (2) and (4) are only a very rough approximation to the actual temperature distribution because of upward or downward advection of ice except near the equilibrium line. Fortunately the annual surface accumulation/ablation rate of the continental-type glaciers in China is quite low, the gradient of mass balance (activity index) ranges from 2.9 to $6.2 \mathrm{~mm} / \mathrm{m}$ in T'ien Shan (Tian Shan) and Ch'i-lien Shan (Qilian Shan) for instance (Xie, 1980), so we can apply these equations approximately to some several hundred metres below equilibrium line.

Table I shows the values of the temperature $T_{0}(16)$ at the lower bound of the active layer, the vertical temperature gradient $\gamma$, and the depth $L$ at which the pressure-melting point appears for several glaciers in China where the temperature has been measured to greater depth. The values in Table I are either calculated, if the observed depth is enough, or extrapolated, if the observed depth is less than $16 \mathrm{~m}$, from the measured data by use of Equations (1), (2), and (4).

Now we are going to compare $L$ with $H$ as observed by the gravimeter method. In the glacier Hsi-ch'iung-t'ai-lan ping-ch'uan (Xi-qiong-tai-lan bing-chuan) $H$ is observed to be $229 \mathrm{~m}$ at average altitude of $3850 \mathrm{~m}$ and its maximum value to be $302 \mathrm{~m}$. It will rise at the altitude shown in Table I and so be much greater than $L$ as in condition (c) above mentioned. In Jung-pu pingch'uan (Rong-bu bing-chuan) the maximum of $H$ is observed to be $146 \mathrm{~m}$ at the altitude of $5350 \mathrm{~m}$ (Xie and Su, 1975), so $H$ is greater than $L$ as in condition (c) too. In No. 5 glacier, Yang-lung he (Yang-long he), there are no data for $H$. But in "Ch'i yi" ping-ch'uan ("Qi Yi" bing-chuan), an adjacent glacier a little bigger than No. 5 glacier, has been observed to be tens of metres with the maximum $H$ of $93 \mathrm{~m}$. Then No. 5 glacier, Yang-lung he (Yang-long he), seems to belong to condition (c) or (b). Thus from the above comparison we can infer the temperature features in deep layers of continental-type glaciers in China as follows: (1) bottom ice and the glacier bed freeze together with permafrost below when the upper-bound temperature of the deep layer is quite low or the glacier is too thin; (2) the interface between ice and the bed is at the pressure-melting point while the bottom ice layer still below the pressure-melting point when the upper-bound temperature is quite low but the glacier is very thick, or the glacier thickness not too large but the upper-bound temperature rather high; (3) there is a temperate ice layer in the lower part of the glacier on thawed ground (rock) when the upper-bound temperature is rather high and the glacier thickness rather great. Cases (2) and (3) usually predominate.

\section{DISCUSSION OF VERTICAL TEMPERATURE GRADIENT AND BASAL SLIDING}

From Table I one can see that $\gamma$ values seem to reduce with decreasing elevation in the same glacier and to be 3.5-8.2 times the gradient needed for the geothermal heat flux to travel

\begin{tabular}{|c|c|c|c|c|c|}
\hline Glacier & $\begin{array}{c}\text { Year of } \\
\text { measurement }\end{array}$ & $\begin{array}{c}\text { Elevation } \\
\mathrm{m}\end{array}$ & $\underset{\mathrm{m}}{\text { Depth }}$ & $\begin{array}{c}T_{0}(16) \\
{ }^{\circ} \mathrm{C}\end{array}$ & $\stackrel{\gamma}{\gamma / \mathrm{m}}$ \\
\hline Hsi-ch'iung-t'ai-lan ping-ch'uan & 1978 & $\begin{array}{l}4050 \\
4300\end{array}$ & $\begin{array}{l}18 \\
16\end{array}$ & $\begin{array}{l}-1.8 \\
-3.0\end{array}$ & $\begin{array}{l}0.104 \\
0.124\end{array}$ \\
\hline No. 5, Yang-lung he & 1977 & $\begin{array}{l}4513 \\
4648 \\
4835\end{array}$ & $\begin{array}{l}16.1 \\
15.8 \\
15.2\end{array}$ & $\begin{array}{l}-6.2 \\
-7.9 \\
-4.9\end{array}$ & $\begin{array}{l}0.083 \\
0.134 \\
0.196\end{array}$ \\
\hline Jung-pu ping-ch'uan & $\begin{array}{l}1966 \\
1964\end{array}$ & $\begin{array}{l}5400 \\
5650\end{array}$ & $\begin{array}{l}10 \\
10\end{array}$ & $\begin{array}{l}-1.0 \\
-3.3\end{array}$ & $\begin{array}{l}0.11 \\
0.14\end{array}$ \\
\hline
\end{tabular}

TABle I. The value of $T_{0}(16), \gamma$, AND $L$ for glaciers in China Where the temperature has BeEn taken at DEPTH

(The altitude of the equilibrium line of each glacier is shown in Table II) 
upwards through the glacier. Recently Müller (1976) has reported a vertical temperature gradient of $0.08 \mathrm{deg} / \mathrm{m}$ measured near the bottom of the glacier at site III (middle part) of White Glacier (lat. $80^{\circ} \mathrm{N}$.) and considers that in this glacier there is basal sliding on most of the glacier bed. Hooke and Koci (1978) report that the gradient between 19 and $23 \mathrm{~m}$ in hole $\mathrm{S}_{25}$ on Sukkertoppen Iskappe, Greenland, is $0.14 \mathrm{deg} / \mathrm{m}$, which corresponds to 7.5 times the gradient needed for the geothermal heat flux at the place in question. The data published by Vilesov (1961) show that in Lednik Tsentralniy Tuyuksu, Zailiyskiy Alatau, a gradient of $0.11 \mathrm{deg} / \mathrm{m}$ was measured between 10 and $20 \mathrm{~m}$ depth at No. 5 hole $600 \mathrm{~m}$ from the front, but the gradient decreased downards, and a temperature of -0.1 to $-0.7^{\circ} \mathrm{C}$ appeared at the bottom, $52 \mathrm{~m}$ in depth. It follows that in cold glaciers $\gamma$ should be greater, several times more than the gradient needed for the geothermal flux. The problem is to extrapolate $\gamma$ from the active layer to the deep layer. According to the circumstances in Lednik Tsentralniy Tuyuksu, which is similar to the continental-type glaciers in China, $\gamma$ in the active layer is larger than that in the deep layer, so that the value of $L$ calculated from Equation (4) probably is a little small. But the basic fact that basal sliding takes place extensively in glaciers in China cannot be changed in any case.

The surface flow velocity observed in the middle and lower parts of glaciers in China shows that without exception the summer velocity is faster than the winter velocity, or than annual mean velocity. For instance, in Lao-hu-kou ping-ch'uan (Lao-hu-gou bing-chuan) the summer velocity is faster than winter velocity by a factor of 1.6 observed from 1960 to 1961 ; in No. 1 glacier, Urumchi river, on the average the summer velocity is faster than winter velocity by a factor of 1.05 to 1.90 , according to Zhang (1965), who summarized the data observed from 1959 to 1962; in "Ch'i yi" ping-ch'uan ("Qi Yi" bing-chuan), the summer velocity is faster than the winter velocity by a factor of 1.06 on the average over seven sections observed from August 1976 to September 1977; in No. 5 glacier, Yang-lung he (Yang-long he), the summer velocity is faster than winter velocity by a factor of 1.22 on the average over eight sections observed from June 1977 to August 1978; in Hsi-ch'iung-t'ai-lan ping-ch'uan (Xi-qiong-tai-lan bing-chuan) the velocity from 10 July to 28 July 1977 , was faster than that from July 1977 to July 1978 by a factor of 1.43 on the average over five sections. This phenomenon indicates that the pressuremelting point appears at the glacier bed, where basal sliding exists, while the melt water percolates to the bed during the ablation period, lubricating and promoting basal sliding.

THE LOWER-BOUND TEMPERATURE OF THE ACTIVE LAYER AT THE ELEVATION OF THE EQUILIBRIUM LINE

Shi and Xie (1964), Huang and Yuan (1965), Division of Glaciology, Lanzhou Institute of Glaciology, Cryopedology and Desert Research (1975), Shi and others (1980) and Zhong-guo Ke-xue-yuan Lanzhou Bing-chuan Dong-tu Yan-jiu-suo (1980) have discussed the regional variation of glacier temperatures in China, giving an impression that the lowest ice temperatures arise in the western section of Ch'i-lien Shan (Qilian Shan), the place where glacier temperatures may be the lowest of all alpine glaciers located in the middle and low latitudes. From there eastwards to middle and eastern section of Ch'i-lien Shan (Qilian Shan), westwards to the middle and western sections of T'ien Shan (Tian Shan) and southwards to the middle Himalaya Shan, the glacial temperature will rise gradually, reflecting the increase of continentality towards the western section of Ch'i-lien Shan (Qilian Shan) from the east, west, and south.

In fact in Table I a comparison of $T_{0}(16)$ is made. But it is better to take the lower-bound temperature, $T_{0}(16)_{\mathrm{E}}$, of the active layer at the elevation of the equilibrium line as a standard for comparison. For this purpose the gradient $\mathrm{d} T_{0}(16) / \mathrm{d} z$ for $T_{0}(16)$ varying with altitude $z$ must be sought.

The data from No. 5 glacier, Yang-lung he (Yang-long he), extending across the equilibrium line is what we need. We can get $\mathrm{d} T_{0}(16) / \mathrm{d} z=-1.26 \mathrm{deg} / 100 \mathrm{~m}$ between $4513 \mathrm{~m}$ and $4648 \mathrm{~m}$ 
TABLE II. ICE TEMPERATURE AT THE LOWER BOUND OF THE ACTIVE LAYER, IN COMPARISON WITH ANNUAL MEAN AIR TEMPERATURE, AT THE ALTITUDE OF THE EQUILIBRIUM LINE

Glacier

Hsi-ch'iung-t'ai-lan ping-ch'uan

No. 5, Yang-lung he

Jung-pu ping-ch'uan

Ye-po-k'ang-chia-le ping-ch'uan

$\begin{array}{cc}\text { Year } & \begin{array}{c}\text { Altitude of } \\ \text { equilibrium line } \\ \mathrm{m}\end{array} \\ 1978 & 4500 \\ 1977 & 4600 \\ 1966 & 5800 \\ 1964 & 6000\end{array}$

$$
\begin{gathered}
T_{\mathrm{E}} \\
{ }^{\circ} \mathrm{C} \\
-8.8 \\
-11.0 \\
-8.5 \\
-9.5
\end{gathered}
$$

for this glacier from Table I. The absolute value is greater than the annual mean vertical airtemperature gradient, estimated to be $-0.74 \mathrm{deg} / 100 \mathrm{~m}$, by $0.52 \mathrm{deg} / 100 \mathrm{~m}$, which may result from upward advection and strain heating. Let us apply $\mathrm{d} T_{0}(16) / \mathrm{d} z=-1.25 \mathrm{deg} / 100 \mathrm{~m}$ to extrapolate $T_{0}(16)_{\mathrm{E}}$ from the elevations below the equilibrium line shown in Table I for the time being. The result is shown in Table II, the annual mean air temperature $T_{\mathrm{E}}$ at the altitude of the equilibrium line is also shown for comparison. We can see from this Table that $T_{0}(16)_{\mathrm{E}}$ ranges from -5.5 to $-7.7^{\circ} \mathrm{C}$. Mentioning the continental-type temperature regime of glaciers, Avsyuk (1956) had indicated that the annual mean temperature of the deep layer is always higher than the annual mean air temperature, and for Soviet Tyan'-Shan' the former is 2 deg higher than the latter. Now we can exactly say that the lower-bound temperature of the active layer (usually lower than the mean temperature of the deep layer) at the altitude of the equilibrium line is 1.8 to $3.7 \mathrm{deg}$ higher than the annual mean air temperature at the same height for continental-type glaciers in China.

\section{VERTICAL ZONES OF THE TEMPERATURE REGIME IN GLACIERS}

\section{Ablation zone}

Most temperature measurements we have taken are in the ablation zone, where a temperature below zero is always measured. The temperature regime of the active layer in the ablation zone can be described by Equation (1) except in the first $3 \mathrm{~m}$, where a complicated heat exchange exists and a zero temperature casing arises in the warmest months. In many smallscale glaciers such as No. 1 glacier, Urumchi river, and No. 5 glacier, Yang-lung he (Yang-long he), a zero temperature casing of less than $0.5 \mathrm{~m}$ was found. The lower-bound temperature of the active layer is generally higher than the annual mean air temperature at the same height, for example, $3.7 \mathrm{deg}$ higher at an altitude of $4513 \mathrm{~m}$ in No. 5 glacier, Yang-lung he (Yang-long he). The pressure-melting point usually appears at the bottom layer of the glacier, at least at the interface between ice and bedrock. Basal sliding exists except at some termini of small glaciers and their margins or some extremely small glaciers like hanging glaciers, which may be entirely below zero and freeze onto bedrock.

The extremely large valley glaciers descend to a region where the climate is warm. The temperature in the active layer of its ablation zone will rise as elevation decreases. The rising rate will be greater than the vertical air-temperature gradient, so that the difference between the annual air temperature and the lower-bound temperature of the active layer gradually increases (of course the pressure-melting point is a limit for the rise of the lower-bound temperature). Finally the ablation zone changes into a temperate glacier.

TABLE III. ICE TEMPERATURE OF BATURA GLACIER IN 1974

$\begin{array}{cccc}\text { Elevation } & \text { Date } & \begin{array}{c}\text { Depth } \\ \mathrm{m}\end{array} & \begin{array}{c}\text { Temperature } \\ { }^{\circ} \mathrm{C}\end{array} \\ 4500 & \text { 11-20 August } & 4.7 & -1.7--1.5 \\ 3300 & \text { 18 July-31 August } & 13 & -0.9-0.5 \\ 2560 & \text { 1 June-31 July } & 8 & 0.0\end{array}$


TABLE IV. TEMPERATURE $\left({ }^{\circ} \mathrm{C}\right)$ OF SNOW LAYER AT $4650 \mathrm{~m}$ A.S.L. IN THE INFILTRATION-CONGELATION ZONE OF No. 5

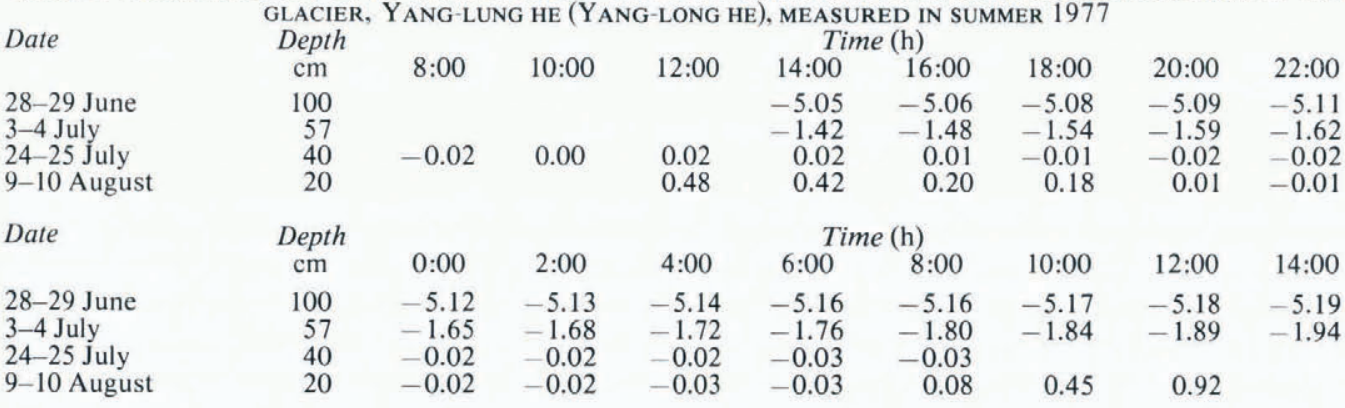

Table III shows the ice temperature of Batura Glacier measured in 1974 by the Batura Glacier Investigation Group, Lanzhou Institute of Glaciology and Cryopedology (1979). Its equilibrium line is located at an altitude between $4700 \mathrm{~m}$ and $5300 \mathrm{~m}$ and its terminus descends down to the bend of the Hunza River at $2540 \mathrm{~m}$ a.s.l. One can see from this Table that its temperature rises as elevation decreases and the lower part of its ablation zone becomes a temperate glacier.

\section{Infiltration-congelation zone (superimposed-ice zone)}

Equation (1) can be applied to describe the temperature in the active layer except in the upper $3 \mathrm{~m}$. The lower bound temperature of the active layer is lower than that in the ablation zone, but is higher than the annual mean air temperature at the same height by a difference smaller than that in the ablation zone, of $3.0 \mathrm{deg}$, for example, at an altitude of $4648 \mathrm{~m}$ in No. 5 glacier, Yang-lung he (Yang-long he). The pressure-melting point generally occurs at the bottom except in some glaciers with extremely small thickness.

The heat exchange in the surface layer is complicated by accumulation, ablation, and the infiltration and recongelation of melt water. Table IV shows the temperature data for the snow layer taken at an altitude of $4650 \mathrm{~m}$ in No. 5 glacier, Yang-lung he (Yang-long he), by means of a quartz thermometer with an accuracy up to $\pm 0.01 \mathrm{deg}$. One can see from Table IV that the snow layer retains quite a low temperature before the melting season while its temperature rises rapidly once the melting season has come. During the main melting season at between $20 \mathrm{~cm}$ and $40 \mathrm{~cm}$ depth the snow temperature is near $0{ }^{\circ} \mathrm{C}$ all day long, with a minimum of $-0.03{ }^{\circ} \mathrm{C}$ before dawn and a maximum over $0.00^{\circ} \mathrm{C}$ at noon, resulting from the thermometer absorbing transmitted radiation.

\section{Infiltration zone}

Accumulation, ablation, and the infiltration and recongelation of melt water play a leading role in the surface layer, profoundly affecting the temperature regime in the active layer. The temperature of the entire active layer in this zone is higher than that in the other zones below it. For example, in No. 5 glacier, Yang-iung he (Yang-long he), $T_{0}(16)$ at the altitude of $4835 \mathrm{~m}$ is

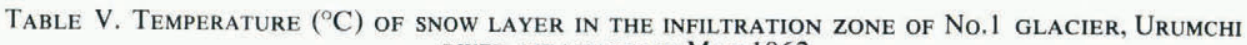

\begin{tabular}{|c|c|c|c|c|c|c|c|c|c|}
\hline Date & & RIVER, & ASURE & IN MA & 1962 & W. surf & $(\mathrm{cm})$ & & \\
\hline Date & Elevation & 26 & & Dept & Delow s & w surf & $2(\mathrm{~cm})$ & & \\
\hline 12 May & 4140 & 25 & $\begin{array}{c}45 \\
-6.4\end{array}$ & 80 & $\begin{array}{r}100 \\
-7.0\end{array}$ & 125 & 125 & 165 & $\begin{array}{c}195 \\
-73\end{array}$ \\
\hline 12 May & 4100 & -0.6 & & -7.2 & & -7.5 & -7.8 & -7.8 & \\
\hline $\begin{array}{l}21 \text { May } \\
21 \text { May }\end{array}$ & 4140 & -01 & -0.2 & 01 & -1.1 & 08 & 08 & 08 & -1.6 \\
\hline & 4100 & -0.1 & & -0.1 & & -0.8 & -0.8 & -0.8 & \\
\hline
\end{tabular}

(from Huang and Yuan, 1965) 
TABle Vi. Temperature at 4100 m A.S.L in the infiltration zone of No. 1 glacier, Urumchi River, MEASURED ON 28 SEPTEMBER 1962

$\operatorname{Depth}(\mathrm{cm})$

Temperature $\left({ }^{\circ} \mathrm{C}\right)$

$\begin{array}{cccccc}30 & 50 & 80 & 160 & 210 & 260 \\ -2.6 & -2.2 & -1.2 & 0.0 & 0.0 & 0.0\end{array}$

$\begin{array}{lccc}310 & 360 & 460 & 560 \\ 0.0 & -0.1 & -0.6 & -1.7\end{array}$

(from Huang and Yuan, 1965)

higher than that at the other two sites (Table I), hence the difference between $T_{0}(16)$ and the annual mean air temperature at the same height grows to $7.3 \mathrm{deg}$. Equation (1) can still be applied to describe the temperature in the active layer except in the upper $3 \mathrm{~m}$. It will be at the pressure-melting point at the bottom in all probability. A temperature of $0^{\circ} \mathrm{C}$ will appear and remain in the upper snow layer in summer. In the snow layer nearest the surface the temperature will lower quickly in winter, with an extreme temperature lower than that in other zones below, but in inner snow layers, the temperature will not lower so much, because there is liquid water within it which releases latent heat as a result of recongelation. Thus a special temperature regime is formed: a quite low surface temperature followed by a quite high inner temperature; a large surface temperature amplitude accompanies a small inner temperature amplitude. Table V shows the temperature before the melting season measured in the infiltration zone of No. 1 glacier, Urumchi river. Table VI shows the temperature after the melting season measured in the same zone. One can see a rapid temperature rise before the melting season and a slow lowering after it, the latter, of course, results from the melt-water store and its recongelation. During the days of intense melting and infiltration there is a snow and ice layer of at least $4 \mathrm{~m}$ falling to the melting point.

It is to be expected that infiltration and recongelation would weaken and disappear with increasing height, and that the primary influence of climatic factors on ice temperature would then again be given full play.

Summing up the above ideas, we can draw a scheme to show how $T_{0}(16)$ changes with glacial zones as Figure 5.

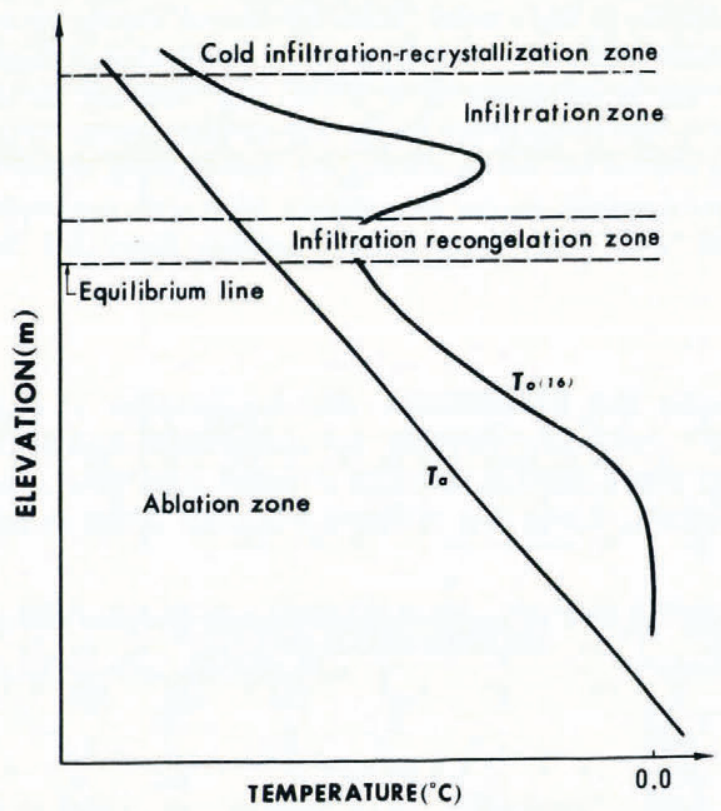

Fig. 5. Diagram showing how the lower-bound temperature in the active layer changes with glacial zones. 


\title{
ACKNOWLEDGEMENTS
}

In this paper we cite many data from Lanzhou Institute of Glaciology and Cryopedology, Academia Sinica that have never previously been published, in particular the data of temperature in Hsi-ch'iung-t'ai-lan ping-ch'uan (Xi-qiong-tai-lan bing-chuan) from Comrade Wang Lilun*, of glacier thickness from Comrade Su Zhen†, of glacier flow velocity from Comrades Sun Zuozhe and Song Guoping Ding Liangfu§, we are grateful to them for their kind support.

\section{MS. received 6 October 1980 and in revised form 5 February 1981}

\author{
* Wade-Giles: Wang Li-lun. \\ † Wade-Giles: Su Chen. \\ * Wade-Giles: Sun Tso-che and Sung Kuo-p’ing. \\ $\S$ Wade-Giles: Ting Liang-fu.
}

\section{REFERENCES}

Avsyuk, G. A. 1956. Temperatura l'da v lednikakh [Temperature of ice in glaciers]. Trudy Instituta Geografii. A kademiya Nauk SSSR, Vyp. 67, p. 63-141.

Batura Glacier Investigation Group, Lanzhou Institute of Glaciology and Cryopedology, Academia Sinica. 1979. The Batura Glacier in the Karakoram Mountains and its variations. Scientia Sinica, Vol. 22, No. 8, p. 958-74. Budd, W. F. 1969. The dynamics of ice masses. ANARE Scientific Reports. Ser. A(IV). Glaciology. Publication No.
108.

Division of Glaciology, Lanzhou Institute of Glaciology, Cryopedology and Desert Research, Academia Sinica. 1975. Basic features of the glaciers of the Mt. Jolmo Lungma region, southern part of the Tibet Autonomous Region,
China. Scientia Sinica, Vol. 18, No. 1, p. 106-30.

Dolgushin, L. D. 1961. Main particuliarities [sic] of glaciation of central Ȧsia according to the latest data. Union Géodesique et Géophysique Internationale. Association Internationale d'Hydrologie Scientifique. Assemblee générale de Helsinki, 25-7-6-8 1960. Commission des Neiges et Glaces, p. 348-58. (Publication No. 54 de l'Association Internationale d'Hydrologie Scientifique.)

Hooke, R. L. and Koci, B. R. 1978. Temperature measurements on the Barnes Ice Cap, Baffin Island, Canada, and on Sukkertoppen Iskappe, Greenland, Journal of Glaciology, Vol. 20, No. 83, p. 441-43. [Letter.]

Huang Maohuan [i.e. Huang Mao-huan] and Yuan Jianmo [i.e. Yuan Chien-mo]. 1965. T'ien Shan Wu-lu-mu-ch'i heyuan yi-hao ping-ch'uan ping-hsueh piao-ts'eng wen-tu chuang-k'uang [The temperature regime of the surface snow and ice layer on No. 1 glacier of Urumchi river source, T'ien Shan]. (In Zhong-guo Ke-xue-yuan di-li Yanjiu-suo Bing-chuan Dong-tu Yan-jiu-shi Bian-ji [i.e. Chung-kuo K'e-hsueh-yuan ti-li Yen-chiu-so Ping-ch'uan Tung-t'u Yen-chiu-shih Pien-chi], ed. T'ien Shan Wu-lu-mu-ch'i-he ping-ch'uan yu shui-wen yen-chiu [Researches
[Rer-ch on the glaciology and hydrology of Urumchi river source, T'ien Shan]. Peking, K'e-hsueh Ch'u-pan-she, p. 25-30.)

Müller, F. 1976. On the thermal regime of a high-Arctic valley glacier. Journal of Glaciology, Vol. 16, No. 74, p.

Ren Jiawen [i.e. Jen Chia-wen] and Huang Maohuan [i.e. Huang Mao-huan]. 1981. Ping-ch'uan huo-tung-ts'eng wentu chuang-k'uang-te ch'uan-je-hsueh fen-hsi [Analysis of heat transfer within glacial active layer]. Bingchuan Dongtu [i.e. Ping-ch'uan Tung-t'u]: Journal of Glaciology and Cryopedology. Vol. 3, No. 3, p. 23-28 [English
summary, p. 28.]

Shi Yafeng [i.e. Shih Ya-feng] and Li Jijun [i.e. Li Chi-chun]. In press. [Glaciological research on the Ch'ing-hai-Hsitsang kao-yuan (Qinghai-Xizang kao-yuan).] [Proceedings of a symposium on Ch'ing-hai-Hsi-tsang kao-yuan,
Peking 25 May-1 June 1980.]

Shi Yafeng [i.e. Shih Ya-feng] and Xie Zichu [i.e. Hsieh Tzu-ch'u]. 1964. Chung-kuo hsien-tai ping-ch'uan-te chi-pen t'e-cheng [Basic features of existing glaciers in China]. Acta Geographica Sinica, Vol. 30, No. 3, p. $183-208$.
[Russian summary, p. 206-08.]

Shi Yafeng [i.e. Shih Ya-feng] and others. 1980. Distribution, features, and variations of glaciers in China, by Shih Yafeng [Shi Yafeng], Hsieh Tzu-ch'u [Xie Zichu], Cheng Pen-hsing [Zheng Benxing], and Li Chi-chun [Li Jijun]. [Union Géodésique et Géophysique Internationale. Association Internationale des Sciences Hydrologiques. Commission des Neiges et Glaces.] Atelier Inventaire Mondial des Glaciers. Actes de l'atelier de Riederalp, Suisse, 17-22 septembre 1978, organisé par le Secrétariat Technique Temporaire pour l'Inventaire Mondial des Glaciers, p. 111-16. (IAHS-AISH Publication No. 126.) [Discussion, p. 125-27.]

Vilesov, E. N. 1961. Temperature of ice in the lower parts of the Tuyuksu glaciers. Union Géodésique et Géophysique Internationale. Association Internationale d'Hydrologie Scientifique. Assemblee générale de Helsinki, 25-7-6-8 1960. Commission des Neiges et Glaces, p. 313-24. (Publication No. 54 de l'Association Internationale d'Hydrologie Scientifique.)

Wang Wenying [i.e. Wang Wen-ying] and others. In press. A surging advance of Balt Bare Glacier, Karakoram Mountains, by Wang Wenying [i.e. Wang Wen-ying], Huang Maohuan [i.e. Huang Mao-huan], and Chen Jianming [i.e. Ch'en Chien-ming]. [Paper presented at International Conference on Recent Advance in Earth Science, Islamabad, 23-25 June 1980.] 
Xie Zichu [i.e. Hsieh Tzu-ch'u]. 1980. Ping-ch'uan wu-chih-p'ing-heng chi ch'i yü ping-ch'uan t'e-cheng-te kuan-hsi [Mass balance of glaciers and its relationship with characteristics of glaciers]. Bingchuan Dongtu [i.e. Ping-ch'uan Tung-t'u]: Journal of Glaciology and Cryopedology, Vol. 2, No. 4, p. 1-10. [English summary, p. 10.]

Xie Zichu [i.e. Hsieh Tzu-ch'u] and Su Zhen [i.e. Su Chen]. 1975. Chu-mu-lang-ma feng ti-ch'ü ping-ch'uan-te fa-yü t'iao-chien, shu-liang chi fen-pu [The development condition, amount, and distribution of glaciers in the region of Chu-mu-lang-ma feng]. (In Zhong-guo Ke-xue-yuan Xi-sang Ke-xue Kao-cha-dui [i.e. Chung-kuo K'e-hsuehyuan Hsi-tsang K'e-hsueh K'ao-ch'a-tui], ed. Chu-mu-lang-ma feng ti-ch'ü k'e-hsueh k'ao-ch'a pao-kao, 1966-1968. Hsien-tai ping-ch'uan yü ti-mao [Reports of a scientific expedition in the region of Chu-mu-lang-ma feng, 1966-1968. Glaciology and geomorphology]. Peking, K'e-hsueh Ch'u-pan-she, p. 1-15.)

Zhang Chang-qing [i.e. Chang Ch'ang-ch'ing]. 1965. T'ien Shan Wu-lu-mu-ch'i he-yuan yi-hao ping-ch'uan ping yuntung chuang-t'ai chi ping-ch'uan hou-tu-te chi-suan. [The ice movement and the calculation of thickness of No. glacier of Urumchi river source, T'ien Shan]. (In Zhong-guo Ke-xue-yuan di-li Yan-jiu-suo Bing-chuan Dong-tu Yan-jiu-shi Bian-ji [i.e. Chung-kuo K'e-hsueh-yuan ti-li Yen-chiu-so Ping-ch'uan Tung-t'u Yen-chiu-shih Pien-chi], ed. T'ien Shan Wu-lu-mu-ch'i-he ping-ch'uan yu shui-wen yen-chiu [Researches on the glaciology and hydrology of Urumchi river source, T'ien Shan]. Peking, K'e-hsueh Ch'u-pan-she, p. 38-51.)

Zhong-guo Ke-xue-yuan Lanzhou Bing-chuan Dong-tu Yan-jiu-suo Qilian Shan Bing-xue Liyong Yan-jiu-dui [i.e. Chung-kuo K'e-hsueh-yuan Lan-chou Ping-ch'uan Tung-t'u Yen-chiu-so Ch'i-lien Shan Ping-hsueh Li-yung Yen-chiu-tui]. 1980. Ch'i-lien Shan ping-ch'uan-te chin-ch'i pien-hua [A preliminary study on recent fluctuation of glaciers in the Ch'i-lien Shan]. Acta Geographica Sinica, Vol. 35, No. 1, p. 48-57. [English summary, p. 57.] 